\title{
LACK OF ASSOCIATION BETWEEN HERPESVIRUS DETECTION IN SALIVA AND GINGIVITIS IN HIV-INFECTED CHILDREN
}

Renata A. OTERO(1), Flávia N.N. NASCIMENTO(1), Ivete P.R. SOUZA(1), Raquel C. SILVA(2), Rodrigo S. LIMA(2), Tatiana F. ROBAINA(2), Fernando P. CÂMARA(2), Norma SANTOS(2) \& Gloria F. CASTRO(1)

\begin{abstract}
SUMMARY
The aims of this study were to compare the detection of human herpesviruses (HHVs) in the saliva of HIV-infected and healthy control children, and to evaluate associations between viral infection and gingivitis and immunodeficiency. Saliva samples were collected from 48 HIV-infected and 48 healthy control children. Clinical and laboratory data were collected during dental visits and from medical records. A trained dentist determined gingival indices and extension of gingivitis. Saliva samples were tested for herpes simplex virus types 1 and 2 (HSV-1 and HSV-2), varicella zoster virus (VZV), Epstein-Barr virus (EBV), and cytomegalovirus (CMV) by nested polymerase chain reaction assays. Thirty-five HIV-infected and 16 control children had gingivitis. Seventeen (35.4\%) HIVinfected children and $13(27 \%)$ control children were positive for HHVs. CMV was the most commonly detected HHV in both groups (HIV-infected, 25\%; control, 12.5\%), followed by HSV-1 (6.2\% in both groups) and HSV-2 (HIV-infected, 4.2\%; control, 8.3\%). The presence of HHVs in saliva was not associated with the presence of gingivitis in HIV-1-infected children $(p=0.104)$ or healthy control children $(p=0.251)$, or with immunosuppression in HIV-infected individuals $(p=0.447)$. Gingivitis was correlated with HIV infection $(p=0.0001)$. These results suggest that asymptomatic salivary detection of HHVs is common in HIV-infected and healthy children, and that it is not associated with gingivitis.
\end{abstract}

KEYWORDS: HIV infection; Herpesvirus; Periodontitis; Gingivitis; Children.

\section{INTRODUCTION}

Herpesviruses are large DNA-enveloped viruses belonging to the Herpesviridae family. Herpesviruses are highly disseminated in nature. Of more than 200 known, eight are human pathogens: herpes simplex virus 1 (HSV-1), herpes simplex 2 (HSV-2), varicella zoster virus (VZV), cytomegalovirus (CMV), Epstein-Barr virus (EBV), and human herpesviruses 6,7 and 8 (HHV-6, -7, -8) $)^{23}$. Transmission occurs by contact, and primary infections generally occur early in life, followed by persistence of the virus in the organism. Herpesvirus diseases occur primarily in immunosuppressed individuals; fatal infections in immunocompetent hosts are rare ${ }^{23}$.

Several studies have implicated herpesviruses in the etiology of periodontitis ${ }^{26-29}$. Apparently, periodontal tissue breakdown occurs more frequently and progresses more rapidly in herpesvirus-infected than in herpesvirus-free periodontal sites ${ }^{26-29}$. Herpesviruses may cause periodontal pathosis as a direct result of virus infection and replication, or as a consequence of virally induced impairment of periodontal immune defenses, resulting in heightened virulence of resident bacterial pathogens ${ }^{8,26}$. The herpesviral-bacterial hypothesis of periodontitis development proposes that active herpesvirus infection initiates periodontal tissue breakdown and that host immune responses against the herpesvirus infection are important components of the etiopathogeny of the disease ${ }^{28}$. The herpesvirus infection triggers the release of proinflammatory cytokines, which have the potential to activate osteoclasts and matrix metalloproteinases and to impair antibacterial immune mechanisms, causing an upgrowth of periodontopathic bacteria ${ }^{28}$.

High frequencies of EBV and CMV genomes have been noted in adults with progressive periodontitis, in localized and generalized aggressive (juvenile) periodontitis, HIV-associated periodontitis, acute necrotizing ulcerative gingivitis, periodontal abscesses, and some rare types of advanced periodontitis associated with medical disorders ${ }^{26}$. Other herpesviruses such as HHV-6, HHV-7, HHV-8, and HSV-1, have also been associated with periodontitis ${ }^{4,15,19}$. In contrast, HSV-2 appears to be uncommon at periodontal sites ${ }^{7,32}$. However, the pathogenesis of herpesviruses in periodontitis has not yet been fully elucidated.

Human herpesviruses (HHVs) have often been detected in the saliva

(1) Department of Pediatric Dentistry, School of Dentistry, Universidade Federal do Rio de Janeiro, RJ, Brazil.

(2) Department of Virology, Microbiology Institute, Universidade Federal do Rio de Janeiro, RJ, Brazil.

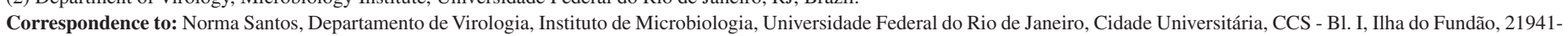
902 Rio de Janeiro, RJ, Brasil. Phone: 5521 2560-8344 extension 165, Fax: 5521 2560-8028. E-mail: nsantos@micro.ufrj.br 


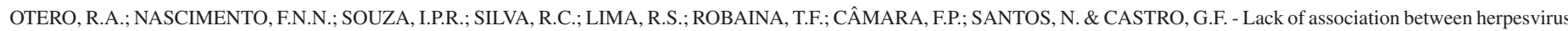
detection in saliva and gingivitis in HIV-infected children. Rev. Inst. Med. Trop. Sao Paulo, 57(3): 221-5, 2015.

of HIV-infected individuals $4,5,7,11,12,15,18$, and several studies have shown that highly active antiretroviral therapy (HAART) does not significantly reduce the prevalence or the load of HHVs in saliva ${ }^{11,17,22,32}$. The elevated frequency of HHVs infections in association with periodontitis in HIVinfected individuals ${ }^{7,8,11,12}$ suggests that these viruses play a role in the disease. In children, the prevalence of some oral manifestations associated with HIV infection was reduced after HAART initiation. However, other lesions emerged ${ }^{24}$, as these individuals are prone to develop opportunistic viral infections, especially those caused by Herpesviridae family members, in the oral mucosa. Little information is available on HHVs co-infection in the saliva of HIV-infected children.

The aims of this study were to detect HHVs in the saliva of HIV1-infected children in comparison with healthy control children, and to evaluate possible associations between viral infection and gingivitis and immunodeficiency stage.

\section{MATERIAL AND METHODS}

Samples: The ethics committees of the Hospital Universitário Clementino Fraga Filho and Institute of Pediatrics and Childcare Martagão Gesteira, Universidade Federal do Rio de Janeiro (UFRJ), Brazil, approved the study protocol. The parents of all children involved in the study provided written informed consent in accordance with Resolution 196/96 of the Brazilian Ministry of Health.

The study population was composed of patients attending the UFRJ School of Dentistry between August 2009 and July 2010. Participants were selected by convenience sampling during initial appointments for dental treatment. The HIV-1-infected group was made up of 48 children of both sexes, ranging from six to 12 years old, who were patients at the Institute of Pediatrics and Childcare Martagão Gesteira, UFRJ, with definitive diagnoses of HIV infection. The following medical history data were extracted from their medical records: diagnosis of HIV infection, results of most recent (closest to the day of saliva sample collection; maximum interval, three months) laboratory tests (viral load, CD4 and CD8 counts, and CD4/CD8 ratio) and use of anti-retroviral agents (at the time of saliva sample collection). The immunodeficiency stages of HIV-infected individuals were defined using CD4 counts, according to the classification of the Centers for Disease Control and Prevention ${ }^{6}$.

The control group consisted of 48 healthy children, ranging from seven to 12 years old, who attended the UFRJ Pediatric Dentistry Clinic and showed no clinical evidence of systemic or chronic disease. They were considered clinically healthy because they were receiving no medical treatment for any disease and showed no clinical sign of immunosuppression, systemic disease, and/or had no history of a risk factor for HIV infection. These data were collected through medical anamnesis with the patients' parents and the attending physician. Children in the control group did not undergo testing to confirm serological HIV negativity because there was no reason to justify this procedure, which the local ethics committees therefore disallowed.

Prior to saliva sample collection, all children in the HIV-1-infected and control groups underwent oral and oropharyngeal examinations by a trained and calibrated dentist to identify oral manifestations such as gum bleeding, mouth ulcers, oral mucosal lesions, and cervical lymphadenopathy. The gingival index was assessed using a sterile periodontal probe. Gingivitis was considered to be present when gingival bleeding occurred on probing ${ }^{1}$. The extension of gingivitis was classified according to the System for the Classification of Periodontal Diseases and Conditions ${ }^{2}$; patients with gingivitis at $<30 \%$ of sites surveyed were classified as having localized gingivitis, and those with $>30 \%$ of surveyed sites affected were classified as having generalized gingivitis.

Individuals were not allowed to brush their teeth or eat for one $\mathrm{h}$ before providing saliva samples. Five milliliters of paraffin-stimulated saliva were collected in a sterile container. The samples were kept in an ice-filled cooler and submitted for laboratory analysis within two h.

Sample processing: The saliva samples were centrifuged and pelleted, and DNA was extracted using the Wizard ${ }^{\circledR}$ Genomic DNA purification kit (Promega, Madison, WI, USA) according to the manufacturer's instructions.

Virus detection: All samples were subjected to human $\beta$-globin gene amplification to determine the integrity and quality of extracted DNA and to avoid false-negative results ${ }^{3}$. Specimens were analyzed using conventional polymerase chain reaction (PCR) assays, as described previously, to detect the presence of $\mathrm{HSV}-1 / 2, \mathrm{VZV}, \mathrm{EBV}$, and $\mathrm{CMV}^{30}$. PCR products were detected using 1.2\% agarose gel electrophoresis and staining with ethidium bromide.

First-round PCR reactions consisted of the addition of $5 \mu \mathrm{L}$ of extracted DNA to $20 \mu \mathrm{L}$ of PCR mix containing $0.5 \mu \mathrm{M}$ of each of the primers HHV-F1 and HHV-R1, $0.125 \mu \mathrm{M}$ of each of the primers VZV-F1 and VZV-R1, and 1x PCR buffer; $1.5 \mathrm{mM} \mathrm{MgCl}_{2}$ and $0.2 \mathrm{mM}$ of deoxyribonucleotide triphosphates; and $2.5 \mathrm{U}$ of GoTaq DNA polymerase (Promega). First-round PCR was carried out as follows: one cycle at 94 ${ }^{\circ} \mathrm{C}$ for three min, followed by 35 cycles at $94{ }^{\circ} \mathrm{C}$ for $45 \mathrm{~s}, 65.5^{\circ} \mathrm{C}$ for one min, $72{ }^{\circ} \mathrm{C}$ for one min, and final extension at $72{ }^{\circ} \mathrm{C}$ for seven min. For nested PCR, $0.5 \mu \mathrm{L}$ of first-round product was transferred to $25 \mu \mathrm{L} \mathrm{PCR}$ mix similar to that described above, but containing second-round primers (HHV-F2, HHV-R2, VZV-F2, and VZV-R2), at the same concentrations as in the first round. PCR conditions were the same as in the first round, except that the annealing temperature was changed to $63^{\circ} \mathrm{C}$. Positive and negative controls were included in each run. Infected cell cultures were used as positive controls for HSV-1 and HSV-2 (Vero cells), EBV (Daudi cells), and CMV (MRC-5 cells). For VZV, clinical samples obtained from patients with varicella diagnoses confirmed by PCR amplification and sequencing analysis were used as positive controls. Negative controls consisted of saliva samples previously demonstrated to be HHVs. The expected sizes of the PCR products for first-round and nested PCRs, respectively, were: HSV-1/2, 742 and 493 pb; VZV, 650 and $356 \mathrm{pb}$; EBV, 748 and 499 pb; and CMV, 817 and 565 pb.

Because some PCR products had very similar sizes, sequencing analysis was used to confirm their specificity and to differentiate HSV-1 and HSV-2. Amplified DNA from all HSV-positive samples and three CMVpositive samples was purified using the Wizard SV gel and PCR clean-up system kit (Promega), and sequences were determined using the BigDye terminator cycle sequencing kit and the ABI PRISM 3100 automated DNA sequencer (Applied Biosystems, Foster City, CA, USA) using the same PCR primers. DNA sequences were edited using the Chromas software (Technelysium Pty. Ltd., Brisbane, QLD, Australia) and compared with the DNA sequences available in GenBank (http://www.ncbi.nlm.nih.gov) 


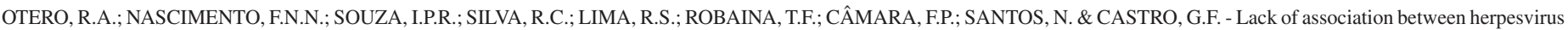
detection in saliva and gingivitis in HIV-infected children. Rev. Inst. Med. Trop. Sao Paulo, 57(3): 221-5, 2015.

using the BLAST tool (http://www.ncbi.nlm.gov/BLAST).

Statistical analysis: Using the Epi-Info statistical program (version 3.5.1., CDC, Atlanta, GA, USA), data from the two groups were compared using the Mann-Whitney test for means of continuous variables (age) and the $\chi^{2}$ test and Fischer's exact tests for categorical variables (sex, presence of HV types in saliva, and gingivitis). Within the HIV-infected group, the $\chi^{2}$ and Fischer's exact tests were used to verify correlations between the presence of HVs in saliva and immunosuppression, HAART, and the presence of oral manifestations.

\section{RESULTS}

The mean age of the 48 HIV-1-infected children was 9.58 years; $45.8 \%$ of these subjects were male, $70.8 \%$ were receiving HAART, and $52.1 \%$ had no immunosuppression. The mean age of healthy control children (47.9\% male) was 9.04 years. There groups did no differ in terms of age or sex $(p>0.05)$. Other clinical and medical data from the study subjects are shown in Table 1.

\section{Table 1}

Demographic, clinical, and immunological characteristics of children in the HIV-1-infected and control groups

\begin{tabular}{lcc}
\hline Variable & $\begin{array}{c}\text { HIV-1-infected } \\
\text { subjects }\end{array}$ & Control subjects \\
\hline $\begin{array}{l}\text { Age (years), mean } \\
\text { (range) }\end{array}$ & $9.58(6-12)$ & $9.04(7-12)$ \\
Sex & Male 22 (45.8\%) & Male 23 (47.9\%) \\
& Female 26(54.2\%) & Female 25 (52.1\%) \\
HAART & Yes, 34 (70.8\%) & \\
& No, 14 (29.2\%) & \\
& $<200 ; 9(18.7 \%)$ & \\
CD4+ count (cells/ $\mu \mathrm{L})$ & $200-499 ; 14(29.2 \%)$ & \\
& $>500 ; 25(52.1 \%)$ & \\
Gingivitis & Yes, 35 (72.9\%) & Yes, 16 (33.3\%) \\
& No, 13(27.1\%) & No, 32 (66.7\%) \\
Oral findings & $\mathrm{n}=4$ & - \\
Candidosis & $\mathrm{n}=5$ & - \\
Linear gingival & $\mathrm{n}=1$ & - \\
erythema & & - \\
Angular cheilitis & & \\
Oral ulcer & & \\
\hline
\end{tabular}

HAART $=$ highly active antiretroviral therapy $;{ }^{1}-$ : absence of symptoms.

Seventeen $(35.4 \%)$ of the 48 HIV-1-infected children were positive for HHVs: $6.2 \%$ (3/48) were positive for HSV-1, 4.2\% (2/48) for HSV-2, and $25.0 \%(12 / 48)$ were positive for CMV. In the control group, 13/48 (27.0\%) children were positive for HHVs: $6.2 \%$ were positive for HSV-1, $8.3 \%$ (4/48) for HSV-2, and $12.50 \%$ (6/48) were positive for CMV. No VZV, EBV or co-infection with those viruses was detected in either group (Table 2). No significant difference was observed in HHVs detection in the saliva of HIV-1-infected and healthy children ( $p=0.167)$; however, HSV-2 was more common in the control group and CMV infection was more common in immunocompromised HIV-1-infected children. Sequence analysis confirmed the PCR results and allowed differentiation between HSV-1 and HSV-2 strains.

Table 2

Herpesviruses detected in saliva from HIV-1-infected and healthy control children

\begin{tabular}{|c|c|c|c|}
\hline Virus $^{1}$ & $\begin{array}{c}\text { HIV-1-infected } \\
\text { subjects }(\%) \\
N=48\end{array}$ & $\begin{array}{c}\text { Control subjects } \\
(\%) \\
N=48\end{array}$ & $p$ \\
\hline HSV-1 & $3(6.2)$ & $3(6.2)$ & 1.00 \\
\hline HSV-2 & $2(4.2)$ & $4(8.3)$ & 0.458 \\
\hline CMV & $12(25.0)$ & $6(12.5)$ & 0.117 \\
\hline Total & $17(35.4)$ & $13(27.0)$ & 0.167 \\
\hline
\end{tabular}

${ }^{1} \mathrm{EBV}$ and VZV were not detected.

HIV-1-infected individuals were classified into three immunologic categories: no evidence of suppression $\left(\mathrm{CD}^{+}>500\right.$ cells $/ \mu \mathrm{L} ; \mathrm{CD}^{+} \%>$ $25)$, moderate suppression $\left(\mathrm{CD}^{+}=200-499\right.$ cells $/ \mu \mathrm{L} ; \mathrm{CD}^{+} \%$ [15-24), and severe suppression $\left(\mathrm{CD}^{+}<200 \text { cells } / \mu \mathrm{L} ; \mathrm{CD} 4^{+} \%<15\right)^{19}$ (Table 1$)$. Twelve of $25(48.0 \%)$ children with no evidence of immunosuppression, $2 / 14(14.3 \%)$ children with moderate immunosuppression, and 3/9 $(33.3 \%)$ children with severe immunosuppression were HHVs positive. No correlation was found between HHV infection and the degree of immunosuppression $(p=0.447)$.

Eleven of 34 (32.4\%) individuals undergoing HAART and 6/14 $(42.8 \%)$ children not receiving HAART were HHVs positive. However, no significant correlation between HHVs detection in saliva and receipt of HAART was observed $(p=0.489)$.

Thirty-five of $48(72.9 \%)$ HIV-1-infected children had gingivitis at the time of sample collection; $10(28.6 \%)$ were positive for HHVs infection. In the control group, six of $16(37.5 \%)$ children with gingivitis were HHVs positive. No significant correlation between the presence of HHVs in saliva and the presence and extension of gingivitis was observed within each group, HIV-1-infected children $(p=0.104)$ and healthy control children $(p=0.251)$, or when the HIV-1-infected group was compared with the control group $(p=0.491)$. However, HIV infection was strongly correlated with gingivitis $(p=0.0001)$.

Four (8.3\%) HIV-1-infected children had candidosis, five (10.4\%) had linear gingival erythema (LGE), one $(2.1 \%)$ had an oral ulcer, and one $(2.1 \%)$ had angular cheilitis (Table 1$)$. One subject with candidosis and LGE and one subject with angular cheilitis were HSV-1 positive; one subject with LGE was CMV positive. HHV detection in saliva was not correlated with any oral symptom.

\section{DISCUSSION}

Herpesviruses, most commonly CMV, EBV, and HSV-1, have been detected in oral samples from immunosuppressed and immunocompetent individuals with gingivitis $7,9,11-13,15,16,18,25,33$. 


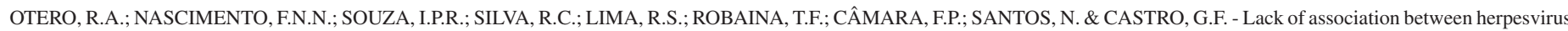
detection in saliva and gingivitis in HIV-infected children. Rev. Inst. Med. Trop. Sao Paulo, 57(3): 221-5, 2015.

Median CMV detection rates in healthy periodontium and in individuals with gingivitis are about $8 \%$ and $33 \%$, respectively ${ }^{27}$. CMV has been detected in $25-49 \%$ of immunocompetent individuals and $40-62 \%$ of HIV-infected individuals with gingivitis ${ }^{11-13,16,33}$. Previous studies have not been able to demonstrate a clear association between the presence of CMV and gingivitis because the virus was detected at high frequencies in control groups. The present study found CMV in the saliva of $25 \%$ of HIV-1-infected children and $12.5 \%$ of healthy control children. Although CMV was detected more often in immunocompromised children, CMV could not be clearly associated with gingivitis.

HSV-1 is detected less frequently than CMV and EBV in the saliva of individuals with periodontitis ${ }^{12,13,25}$, but its detection has been described in patients with gingivitis ${ }^{11,16}$. The present study found HSV-1 in the saliva of $6.2 \%(3 / 48)$ of subjects from both groups.

HSV-2 is rarely detected in saliva ${ }^{7,20,27,31,32}$, but it was detected in both groups in the present study. Two HIV-1-infected boys aged 10 and 11 years were HSV-2 positive; one of these subjects, a severely immunosuppressed $\left(\mathrm{CD}^{+}\right.$count $=149$ cells $\left./ \mu \mathrm{L}[11.27 \%]\right)$ boy who was not undergoing HAART, had gingivitis. The other HIV-1-infected, HSV-2-positive child had no evidence of immunosuppression $\left(\mathrm{CD}^{+}\right.$ count $=724$ cells $/ \mu \mathrm{L}[29 \%]$ ) and was receiving HAART. Four children (aged 7-9 years) in the control group were HSV-2 positive; three of them had gingivitis.

A recent review of $\mathrm{HHV}$ s in periodontitis showed that $\mathrm{EBV}$ is detected in association with gingivitis in $20 \%$ of cases and with healthy periodontium in $8 \%$ of $\operatorname{cases}^{27}$. Several studies have described EBV detection rates of 48-90\% in the saliva of HIV-infected individuals ${ }^{9,14,16,17}$ and $17-40 \%$ in the saliva of healthy individuals ${ }^{5,11,14-16,22}$. Surprisingly, the present study did not detect EBV in HIV-1-infected or healthy children with or without gingivitis.

Few studies have reported VZV excretion in saliva. Such excretion is usually observed in stressed individuals ${ }^{20}$ or those with herpes zoster manifestations ${ }^{10,21}$. WANG et al. ${ }^{32}$ detected VZV DNA in the saliva of $5.1 \%(3 / 59)$ of HIV-positive subjects and $1.9 \%$ (1.53) of healthy control subjects. They detected VZV in individuals undergoing HAART and concluded that such an event is infrequent in the saliva of asymptomatic HIV-positive persons and that HAART does not reduce the risk of asymptomatic VZV excretion ${ }^{32}$. Accordingly, VZV has not been associated with periodontal disease ${ }^{27}$. Consistent with these findings, the present study did not detect VZV in its study population.

In this study, HHVs detection in the saliva of HIV-1-infected and healthy children with and without gingivitis was compared. Although sample size potentially limits the statistical power of the results, the study's findings are comparable to those reported in the literature. CMV was the most prevalent virus detected in both groups, followed by HSV-1 and HSV-2. EBV and VZV were not detected in either group. No association was demonstrated between HHV detection in saliva and the presence of gingivitis. No association between the detection of $\mathrm{HV}$ DNA in saliva and the level of immunosuppression in HIV-1-infected children was observed. Moreover, HAART did not seem to reduce virus shedding. However, a strong correlation between HIV infection and gingivitis was confirmed.

\section{RESUMO}

\section{Ausência de associação entre a detecção de herpesvírus na saliva e gengivite em crianças infectadas pelo HIV}

Os objetivos deste estudo foram detectar a presença de herpesvírus humanos (HHVs) na saliva de crianças infectadas pelo HIV, em comparação com controles saudáveis e avaliar a associação entre infecção viral, gengivite e imunodeficiência. Para este fim, foram colhidas amostras de saliva de 48 crianças HIV-positivas e 48 controles saudáveis. $\mathrm{O}$ índice gengival e extensão de gengivite foram determinados por um dentista treinado. Informações clínicas e laboratoriais foram obtidas durante a consulta odontológica e dos registros médicos. As amostras de saliva foram testadas para detecção de vírus herpes simplex tipos 1 e 2 (HSV-1 e HSV-2), vírus da varicela-zoster (VVZ), vírus Epistein-Barr (EBV) e citomegalovírus (CMV) através de nested-PCR. Trinta e cinco crianças HIV-positivas e 16 crianças do grupo controle apresentavam gengivite. Dezessete $(35,4 \%)$ crianças HIV-positivas e 13 (27\%) crianças controle testaram positivo para a presença de HHVs. CMV foi o vírus mais comum detectado em ambos os grupos (25\% HIV-positivas e 12,5\% de controle), seguido por HSV-1 (6,2\% de ambos os grupos) e HSV-2 (4,2\% HIV-positivas e 8,3\% de controle). Não houve associação entre a detecção de HHVs na saliva e a presença de gengivite em ciranças HIV-positivas ( $p=0.104$ ) ou crianças saudáveis $(p=0,251)$, ou com imunossupressão em indivíduos HIV-positivos $(p=0,447)$. Foi observada uma correlação entre a infecção por HIV e a presença de gengivite ( $p$ $=0,0001$ ). Os resultados sugerem que a detecção salivar assintomática de HHVs é comum entre crianças HIV-positivas e crianças saudáveis, e não está associada à gengivite.

\section{ACKNOWLEDGMENTS}

This study was supported in part by Conselho Nacional de Desenvolvimento Científico e Tecnológico (CNPq), Coordenação de Aperfeiçoamento de Pessoal de Nível Superior (CAPES) and Fundação Carlos Chagas de Amparo à Pesquisa do Estado do Rio de Janeiro (FAPERJ), Brazil.

The authors thank Soluza dos Santos Gonçalves for technical assistance.

\section{CONFLICT OF INTEREST}

The authors declare that they have no conflict of interest.

\section{AUTHORS' CONTRIBUTIONS}

GFC, IPRS, and NS conceived and designed the study and analyzed the data. RAO, FNNN, RCS, and RSL were responsible for data and sample collection and PCR analysis. All authors have read and approved the final manuscript.

\section{REFERENCES}

1. Ainamo J, Bay I. Problems and proposals for recording gingivitis and plaque. Int Dent J. 1975;25:229-35

2. Armitage GC. Development of a classification system for periodontal diseases and conditions. Ann Periodontol. 1999;4:1-6. 
OTERO, R.A.; NASCIMENTO, F.N.N.; SOUZA, I.P.R.; SILVA, R.C.; LIMA, R.S.; ROBAINA, T.F.; CÂMARA, F.P.; SANTOS, N. \& CASTRO, G.F. - Lack of association between herpesvirus detection in saliva and gingivitis in HIV-infected children. Rev. Inst. Med. Trop. Sao Paulo, 57(3): 221-5, 2015.

3. Bauer HM, Manos MM. PCR detection of genital human papillomavirus. Diagnostic molecular microbiology: principals and applications. Washington: American Society for Microbiology; 1993. p. 407-13.

4. Bilichodmath S, Mangalekar SB, Sharma DC, Prabhakar AK, Reddy SB, Kalburgi NB, et al. Herpesviruses in chronic and aggressive periodontitis patients in an Indian population. J Oral Sci. 2009;51:79-86.

5. Carvalho KS, Silvestre EA, Maciel SS, Lira HI, Galvão RA, Soares MJ, et al. PCR detection of multiple human herpesvirus DNA in saliva from HIV-infected individuals in Teresina, State of Piauí, Brazil. Rev Soc Bras Med Trop. 2010;43:620-3.

6. Centers for Disease Control and Prevention (CDC). Revised classification system for human immunodeficiency virus infection in children less than 13 years of age. MMWR Recomm Rep. 1994;43(RR-12):1-19.

7. Contreras A, Mardirossian A, Slots J. Herpesviruses in HIV-periodontitis. J Clin Periodontol. 2001;28:96-102.

8. Contreras A, Slots J. Herpesviruses in human periodontal disease. J Periodontal Res 2000;35:3-16

9. Di Luca D, Mirandola P, Ravaioli T, Dolcetti R, Frigatti A, Bovenzi P, et al. Human herpesviruses 6 and 7 in salivary glands and shedding in saliva of healthy and human immunodeficiency virus positive individuals. J Med Virol. 1995;45:462-8.

10. Druce J, Catton M, Chibo D, Minerds K, Tyssen D, Kostecki R, et al. Utility of a multiplex PCR assay for detecting herpesvirus DNA in clinical samples. J Clin Microbiol. 2002;40:1728-32.

11. Grande SR, Imbronito AV, Okuda OS, Lotufo RF, Magalhães MH, Nunes FD. Herpes viruses in periodontal compromised sites: comparison between HIV-positive and -negative patients. J Clin Periodontol. 2008;35:838-45.

12. Grande SR, Imbronito AV, Okuda OS, Pannuti CM, Nunes FD, Lima LA. Relationship between herpesviruses and periodontopathogens in patients with HIV and periodontitis. J Periodontol. 2011;82:1442-52.

13. Grenier G, Gagnon G, Grenier D. Detection of herpetic viruses in gingival crevicular fluid of patients suffering from periodontal diseases: prevalence and effect of treatment. Oral Microbiol Immunol. 2009;24:506-9.

14. Guilherme BP, Ferreira DC, Rôças IN, Provenzano JC, Santos KR, Siqueira JF Jr. Herpesvirus carriage in saliva and posttreatment apical periodontitis: searching for association. Oral Surg Oral Med Oral Pathol Oral Radiol Endod. 2011;112:678-83.

15. Hernádi K, Csoma E, Adám B, Szalmás A, Gyöngÿosi E, Veress G, et al. Association of human herpesvirus 6 subtypes with symptomatic apical periodontitis. Oral Surg Oral Med Oral Pathol Oral Radiol Endod. 2011;112:401-6.

16. Imbronito AV, Okuda OS, Maria de Freitas N, Moreira Lotufo RF, Nunes FD. Detection of herpesviruses and periodontal pathogens in subgingival plaque of patients with chronic periodontitis, generalized aggressive periodontitis, or gingivitis. J Periodontol. 2008;79:2313-21.

17. Ling PD, Vilchez RA, Keitel WA, Poston DG, Peng RS, White ZS, et al. Epstein-Barr virus DNA loads in adult human immunodeficiency virus type 1-infected patients receiving highly active antiretroviral therapy. Clin Infect Dis. 2003;37:1244-9.
18. Lucht E, Brytting M, Bjerregaard L, Julander I, Linde A. Shedding of cytomegalovirus and herpesviruses 6,7 , and 8 in saliva of human immunodeficiency virus type 1-infected patients and healthy controls. Clin Infect Dis 1998;27:137-41.

19. Mardirossian A, Contreras A, Navazesh M, Nowzari H, Slots J. Herpesviruses 6, 7 and 8 in HIV- and non-HIV-associated periodontitis. J Periodontal Res. 2000;35278-84

20. Mehta SK, Cohrs RJ, Forghani B, Zerbe G, Gilden DH, Pierson DL. Stress-induced subclinical reactivation of varicella zoster virus in astronauts. J Med Virol. 2004;72:174-9.

21. Mehta SK, Tyring SK, Gilden DH, Cohrs RJ, Leal MJ, Castro VA, et al. Varicella-zoster virus in the saliva of patients with herpes zoster. J Infect Dis. 2008;197:654-7.

22. Miller CS, Berger JR, Mootoor Y, Avdiushko SA, Zhu H, Kryscio RJ. High prevalence of multiple human herpesviruses in saliva from human immunodeficiency virusinfected persons in the era of highly active antiretroviral therapy. J Clin Microbiol. 2006;44:2409-15.

23. Pellett PE, Roizman B. The family Herpesviridae: a brief introduction. In: Fields'virology. $5^{\text {th }}$ ed. Philadelphia: Lippincott-Raven; 2007. v. 2. p. 2479-99.

24. Pinheiro RS, Ferreira DC, Nóbrega F, Santos NSO, Souza IPR, Castro GFBA. Current status of herpes virus identification in the oral cavity of HIV-infected children. Rev Soc Bras Med Trop. 2013;46:15-9.

25. Saygun I, Kubar A, Sahin S, Sener K, Slots J. Quantitative analysis of association between herpesviruses and bacterial pathogens in periodontitis. J Periodontal Res. 2008;43: $352-9$.

26. Slots J. Herpesviruses in periodontal diseases. Periodontol 2000. 2005;38:33-62.

27. Slots J. Human viruses in periodontitis. Periodontol 2000. 2010a;53:89-110.

28. Slots J. Herpesviral-bacterial interactions in periodontal diseases. Periodontol 2000. 2010b;52:117-40

29. Slots J. Oral viral infections of adults. Periodontol 2000. 2009;49:60-86.

30. Tafreshi NK, Sadeghizadeh M, Amini-Bavil-Olyaee S, Ahadi AM, Jahanzad I, Roostaee MH. Development of a multiplex nested consensus PCR for detection and identification of major human herpesviruses in CNS infections. J Clin Virol. 2005;32:318-24.

31. Wald A, Ericsson M, Krantz E, Selke S, Corey L. Oral shedding of herpes simplex virus type 2. Sex Transm Infect. 2004;8:272-6.

32. Wang CC, Yepes LC, Danaher RJ, Berger JR, Mootoor Y, Kryscio RJ, et al. Low prevalence of varicella zoster virus and herpes simplex virus type 2 in saliva from human immunodeficiency virus-infected persons in the era of highly active antiretroviral therapy. Oral Surg Oral Med Oral Pathol Oral Radiol Endod. 2010;109:232-7.

33. Wu YM, Yan J, Ojcius DM, Chen LL, Gu ZY, Pan JP. Correlation between infections with different genotypes of human cytomegalovirus and Epstein-Barr virus in subgingival samples and periodontal status of patients. J Clin Microbiol. 2007;45:3665-70.

Received: 30 July 2014

Accepted: 19 August 2014 